Open Access

\title{
Multifunctional agriculture: an approach for entrepreneurship development of agricultural sector
}

Somayeh Tohidyan Far and Kurosh Rezaei-Moghaddam*

\author{
* Correspondence: \\ rezaei@shirazu.ac.ir; dr. \\ rezaeimoghaddam@gmail.com \\ Department of Agricultural \\ Extension and Education, School of \\ Agriculture, Shiraz University, Fars \\ Province, Shiraz City, Bajgah Region, \\ Iran
}

\begin{abstract}
The purpose of this paper is to compare and analyze agricultural transition periods in order to provide a new framework for agricultural development in Iran. Considering the foreseeable future, an innovative or knowledge-based economy will substitute the obsolete economy. In that respect, agriculture sector must adapt to these alternations in order to cope with the posed challenges. Multifunctional agriculture seems to be an enhanced alternative in which entrepreneurship is at the center of it. The results indicate that the focus of the Nation's policies is on agricultural productivism, as well as the assertion of developmental programs that are toward the more involvement of post-productivism in decision-making. Though, the need for entertaining and establishing a more comprehensive conception on Iranian rural and agricultural thought and practice is sensible. It seems that Iran can also benefit from multifunctional agriculture toward sustainability and the production of healthy food. To move toward multifunctional agriculture, which is the same as entrepreneurial agriculture, at first, the economic theory, which is upheld, ought to be altered and taken toward an innovative economy. As a consequence, the agricultural system should also be changed and multifunctional agriculture should be considered while environmental considerations need to be enabled to achieve more entrepreneurial agriculture. To achieve this feat, agricultural education as an enabler of developing non-traditional attitude, entrepreneurial intentions, competencies, identities, and entrepreneurial experiences among young future farmers should not be ignored.
\end{abstract}

Keywords: Entrepreneurial agriculture, Productivism, Post-productivism, Multifunctionality

\section{Introduction}

In the last few decades, a sustainable and rapid economic growth and development has been one of the important priorities of policy making in different countries while considering both developed and developing countries (Yazdani and Saeedi 2014). In terms of economic development, countries are classified into three categories: factor driven, efficiency driven and innovation driven (Acs et al. 2008). Factor-driven countries are the countries that do not create knowledge for innovation, and it is expected that self-employment rates in the abovementioned countries will be high in non-agricultural sectors. In that sense, the emphasis of the factor-driven economy is mostly on increasing economic outcomes by applying growth

(c) The Author(s). 2019 Open Access This article is distributed under the terms of the Creative Commons Attribution 4.0 International License (http://creativecommons.org/licenses/by/4.0/), which permits unrestricted use, distribution, and reproduction in any medium provided you give appropriate credit to the original author(s) and the source, provide a link to the Creative Commons license, and indicate if changes were made. 
policies and through the use of input variables such as labor, natural resources, and the promotion of external investment. Reflecting upon the undeveloped countries, they often have a large agricultural sector with economic development of natural resources and extractive industries which include an increase in the excessive migration of workers to these specific economic areas. Concerning the mentioned economy, companies are involved in price competition and the use of unskilled labor and natural resources. On the other side, in efficiency-driven economies, economic growth is done through the addition of value to primary production. In these types of economies, the production efficiency methods help better function. The higher level of education and the ability to utilize existing technology, the more are the chances of leading to competitiveness. However, the rate of entrepreneurship in these countries is commonly low. To elaborate further, innovation-driven economies are synonymous with the development of new products and services. As the economy develops, the transition from industrial activities toward service development is done to meet the needs of the growing population. In this fashion, the increase of access to education changes to the ability of the industrial sectors to evolve and produce more various and complex products. In these types of economies, companies make innovative products through sophisticated technology, and innovation is the only way for companies to survive (Bosma et al. 2012; Acs et al. 2008).

Due to rapid expansion of information technology and the development of knowledge in various dimensions, the traditional structures of the economic systems are noticeably altering and enhancing in most countries. According to most specialists, over the next few years, an innovative-driven or knowledge-based economy, in which the production and the use of knowledge and innovation as a source of gaining wealth and competitive advantage, will replace current traditional economics. Although knowledge-based economy is one of the new issues that has been raised over the past decade but it was coherently and scientifically developed by the Organization for Economic Cooperation and Development in 1996 as a prerequisite for the development of such countries. Accordingly, these countries have committed to design all of their infrastructure and social and economic sectors based on the development of a knowledge-based economy, while taking the design and implementation of a coherent planning into account (Peng 2007). Figure 1 shows the stages of economic force.

In recent decades, there had been a lot of theoretical discussion over the role and the importance of the agricultural sector in the field of economic development and planning. In that sense, development specialists believe that the support and stimulus of rural development is agricultural development and agriculture has invariably played a decisive role in rural development which is considered as the main basis of rural development. Agriculture is considered as the main factor in resource conservation, self-sufficiency (in the basic products of each country), rural development, and social and cultural benefits (Wilson 2007). Because of some challenges such as inequality and chaos in employment, lack of entrepreneurial orientation and productive investment in the agricultural sector, inefficiency of policies, unmotivated and inefficiency of the private sectors, technological backwardness and infrastructure underdevelopment, inefficiency of the supportive system, erosion of natural resources and production capacities, vulnerability of a large part of beneficiaries in the agricultural sector, human erosion in the agricultural sector, the inability of beneficiaries in the agricultural sector for constructive competition in regional and international markets due to the lack of 


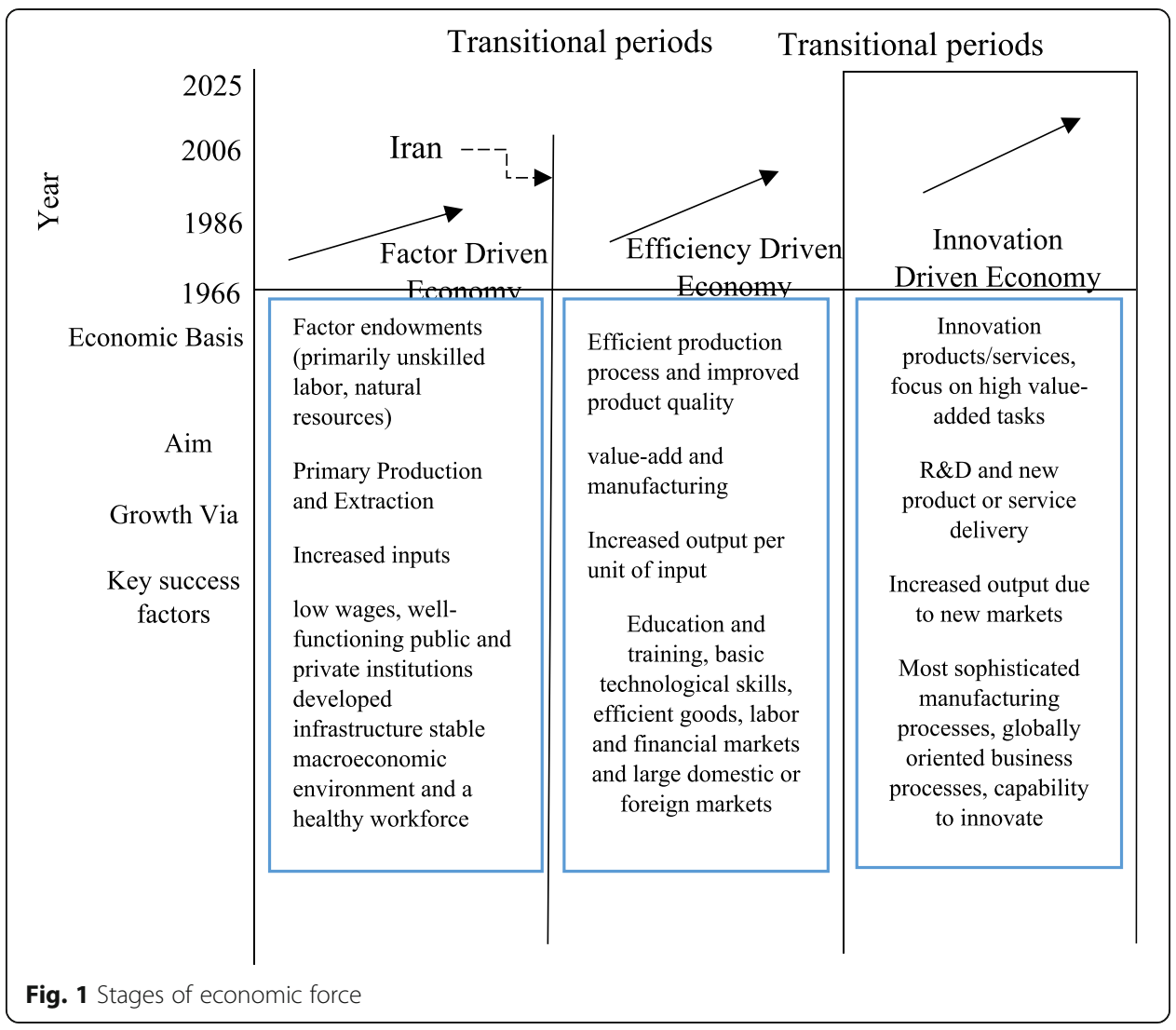

proper utilization of the relative advantages and the lack of development in agricultural chains to achieve value added and transition and unplanned evolution of production and utilization, structure of the agricultural sector and etc. (Kalantari et al. 2008; Karbasioun et al. 2008) agricultural sector and rural areas still lags far behind its real potential in Iran (Darvishi 2003). Entrepreneurial activities are considered as a response to these challenges. Therefore, based on the above, the development of innovative products and new businesses in agricultural sector should be considered as a main priority in policy making (Yazdani and Saeedi 2014; Wilson and Wilson 2001; Wiklund and Shepherd 2005). So considering the foreseeable future, an innovative or knowledge-based economy will substitute the obsolete economy. In that respect, agriculture sector must adapt to these alternations in order to cope with the posed challenges.

The purpose of this paper is to compare and analyze agricultural transition periods in order to provide a new framework for agricultural development in Iran. In this regard, three steps were considered. In the first step, researchers review of the literature on different periods of agricultural transition in the world that finally, the characteristics of three periods of transition from four dimensions of philosophy, strategy and purpose, researchers, and agricultural extension and a view on farm and farmers were compared and analyzed. In the second step, the study of the agricultural situation in Iran was carried out and ultimately in the third step, the content of six developmental plans of Iran was considered according to the categories and subcategories of agricultural transition periods, the emphasis rate of various agricultural periods during the six development plans has been identified and compared with each other. 


\section{Agricultural transition periods}

Over time, dramatically changes have occurred in agricultural system. Changes that agriculture has experienced over thousands of years have been fundamental and even "revolutionary" (Wilson 2007). "The dominant agricultural regime from 1945 to the mid-1980s has been termed 'productivism, a term which relates to policy concepts aimed at maximizing agricultural production" (Woods 2010). In this period, the theory of modernization as the basis for the agricultural development was the basis for activities and it was assumed that agricultural development would take place through the movement of traditional and livelihood agriculture to modern and commercial agriculture (Rezaei-Moghaddam et al. 2005). The theorists of this period define modernity in a general model of social development with the purpose of economic growth. In this model, human, regardless of ethics, seeks only to earn more finance and consumerism (Jenkins 2000). Under such scenario, one of the most important agricultural events during this period was the green revolution. The advocates of the green revolution thought that agricultural development was dependent on the application of standardized input packages, including fertilizers, pesticides, or integrated pest management. For this, the government should provide the necessary funding. This standard approach was well suited for government bureaucracies. The consequences of the green revolution were the rapid and extensive increase of agricultural production, the widespread demand for labor, and the development of the idea that famine was ended and a matter of past (Vermillion 2000). In general, although the modernization theory and the green revolution seemed to have succeeded, the question that raised was whether this success was sustainable or not? Moreover, does this meet the needs of communities? Apparently, the answer was negative (Vermillion 2000). In fact, the consequences of this thinking were increase in the class gap between the poor and the rich, the high growth of consumerism, the increase of environmental problems (due to the modernization process), the overuse of inputs and imported technologies, and, finally, the weakening of traditional values in rural societies (Rezaei-Moghaddam et al. 2005; Ahmadvand and Karami 2007; Vermillion 2000). Many agriculturally productive countries began to look for new export markets that inevitably led to some type of a commerce war, which in turn led to the collapse of global commodity prices and the economic crisis in agriculture in the late 1980s in many developed countries (Essex 2005). In fact, in the mid-1980s, the rationale or the basis and the morality of productivism were intensely questioned because of ideological, environmental, economic, and structural problems; thus, some researchers argued that the ideology of productivism has irregularity and increasing tendency toward post-productivism was created (Wilson 2007). Therefore, the observation of the existing limitations in development thinking over the past decades has emphasized the expanding of a human development paradigm and the application of more participatory approaches for development (Rumbewas 2005). Unlike productivism, it is not easy to determine the exact dimensions for post-productivism. Therefore, there are theoretical, empirical, and conceptual arguments about the nature, speed, and even the transition of productivist to post-productivist (Mather et al. 2006; Wilson 2007). Post-productivism has been used as a concept since the 1990s. It is believed that for some advanced countries, the post-productivism era has begun since 1980s (Wilson 2007). Post-productivism and productivism are placed on both opposite sides of a spectrum (Mather et al. 2006). Post-productivism is an approach that is sensitive regarding environment, and where 
farmers may seek to non-agricultural use of their land and resources to improve their incomes (Jack 2007). Due to the lack of a clear definition and its focus on agriculture, its implementation in some countries and the limited debate on the concept's applicability in other countries, as well as the lack of empirical evidence to support the theory, post-productivism has been criticized (Mather et al. 2006; Wilson 2001).

The reality of the agricultural community in the European Union shows that the most actors are located between productivist and post-productivist in action and thought. To put that into context, many farmers, despite having environmental behaviors or participating in environmental projects, still have productivism thoughts. For this reason, instead of using the concept of post-productivism, a newer concept is used as multi-functional agriculture. The concept of multifunctionality was first introduced in the context of the Rio Earth Summit in 1992 and the members of the Organization for Economic Cooperation and Development developed it in 1998 and since then, there had been an increasingly cited in policy and scientific discussions on the future of agriculture and rural development (Illinois 2015). The statement of the OECD says: agricultural activities beyond the primary role of agriculture in providing food and fiber, can have a role in the development of environmental perspective and benefits, such as land conservation, sustainable management of renewable natural resources, and the preservation of biodiversity, and rural economic and social stability. Furthering this meaning, agriculture will then have several functions that, in addition to the primary role of food and fiber production, have one or more other functions (DeVries 2000). MFA concept plays an important role in opening up a new innovative perspective on key issues such as the developing relationship between agriculture and society and the changing role of agricultural activities in sustainable rural development (Renting et al. 2009). As a concept, multifunctionality "better encapsulates the diversity, non-linearity and spatial heterogeneity in rural society" (Wilson 2001).

\section{A comparison of agricultural transition periods Philosophy of three transitional periods}

One of the most important differences between productivism, post-productivism, and multifunctional agriculture is in their philosophical perception of the world. Considering PA, it derives from an era of modernization in which it is perceived to contribute to 'progress', in positivism and materialistic worldview (Brouma 2003; Wilson 2007). Theorists of this view define modernity in a general model of social development whose main purpose is economic growth (Jenkins 2000). Post-productivism and multifunctionality emphasize the plurality, multiplicity, individuality, and dispersion of concepts rather than the accepted concepts homogeneous, general, comprehensive or universal in productivism. In fact, postmodernism is opposed to unity and convergence, and believes in the multiple realities and pluralism (Evans et al. 2002). Post-productivism and multifunctionality requires a reorientation from focusing on economic growth to focusing on sustainable development (Phelan 2014; Wilson 2007).

The emphasis of productivism is on the increase in income and has a farming-basis perspective, and the village is considered as a place of production, while in post-productivism, agriculture loses its central position in rural communities and the village is considered as a place for consumption, not just for production. 
Post-productivism paradigm was argued that farming would no longer be a main driver for a rural economy while other land-uses gain prominence. The focus of post-productivism is on environmental values (Knickel and Renting 2000; Marsden et al. 2002). To observe multifunctional agriculture, it is necessary to revise the semantic and physical-spatial goals of the village. The multifunctional concept, while paying attention the agricultural sector, acknowledges new activities in rural areas, and emphasizes a new mix of production, consumption and conservation goals (Goodman 2004; Marsden and Sonnino 2008; Wilson 2007). Wilson conceptualized multifunctional agriculture as a spectrum bound of production and non-production thought and action. While production thought and action focus on the production of food and fibers, non-production thought and action focus on generating new sources of income through the expansion of new businesses (Wilson 2008). The focus of multifunctional agriculture is on ecosystem services, building new markets for environmental services, and stimulating diversification (Wilson 2009).

\section{Strategies and purpose of three transitional periods}

The purpose of productivism was to increase production for achieving self-sufficiency at the national and local levels. In post-productivism, achieving self-sufficiency was diminished. In multifunctional agriculture, it is emphasized that food security and self-sufficiency are inextricably related, which is why achieving self-sufficiency was re-emphasized (Wilson 2007). Productivism is associated with specialization, and the focus of agricultural production is on the transformation and evolution of mixed agricultural units into specialized agricultural units or livestock farming businesses. This led to an increase in the opportunity for large economical farms and, on the other hand, to reduction of the opportunities for small family farms (Wilson 2007). In post-modern agriculture the emphasis has been placed on shifting agricultural production toward attention to local and suburban areas, and more attention has been paid to the role of those who have been neglected in previous systems (such as the poor and smallholder farmers) (Wilson 2007). In this type of agriculture, the use of external inputs decreased. In MFA, agricultural sector stimulates diversification and innovative entrepreneurship. Multifunctional system has a systemic and more global viewpoint, which means that through agricultural activities, commodity will be produced that are not necessarily provided for market demand but production of them is due to agricultural activities. In terms of multifunctional farming, environmental considerations have a high footprint. In this regard, consideration of green spaces and natural perspectives and correct nutrition are among the most important ones (Phelan 2014; Wilson 2007). In other words, multifunctional agriculture provides the opportunity to go beyond productivity issues and market competition toward sustainable development topics and strategies (Losch 2004). Quantity has been emphasized more than quality by productivism (Wilson 2007). During this period, the modernization and industrialization of agricultural systems have led to an overproduction of many basic foodstuffs. Farmers have intensified production and specialized in fewer enterprises (Ilbery 1991). Therefore, the common agricultural policy until the early 1980s was almost entirely focused on providing a political framework for increasing agricultural production and encouraging agricultural intensification (Evans et al. 2002). As part of this process, farmers 
have been placed on a treadmill where the decline in food demand relative to income levels leads to the costs of production to rise at a greater rate than the price of food (Ilbery 1991).

The political period after 1985 was changed from intensification toward non-limited and extensification in agriculture, from focusing on production to preserving diversity and quantitative maximization of production to less production but more qualified (Phelan 2014). For post-productivism supporters, one of the important reasons for the support of the transition from agricultural productivism to post-productivism is the recent growth of interest and attention to quality of food (Evans et al. 2002). In MFA system, the close relation with the market and the transition from the livelihood approach has led to a fundamental shift in the structure of agricultural production. Under the pressure of the market mechanisms and the technological and mechanization changes a kind of informal reforms are in progress, the effects of which can be combination and integration of some agricultural systems and the dissolution of other systems that are not able to balance the effective changes. Concurrent with the changes in the conventional production and utilization structure, along with conventional utilization systems, it can be traced that the rise of agricultural businesses to cover all agricultural chains with an entrepreneurial approach. These businesses, due to the multiplicity of constituent components, are integrated and dynamic universality, process-oriented, and program-oriented and are formed in line with profitability, value-added, dual equilibrium of supply and demand dimensions with priority of demand dimension (demand-basis), competitive and market orientation activities, innovation, and the combination of technology and the combination of resource productivity and have an entrepreneurial approach (APO 2003; Kanniainen and Timo 2005; Kreft et al. 2005).

Productivism decisions are focused on, externally developed innovations in mechanization, in animal and plant breeding and in pasture management (Galloway and Mochrie 2005; Fernandez-Cornejo et al. 2007). The intensification and pursuit of productivity through investing in machinery, infrastructure, and the use of chemicals and biotechnology is the techniques of agricultural productivism (Phelan 2014). The decline in agricultural labor force by increasing the mechanization of farms is a characteristic of productivism. In order to profit economically, there was a necessity for farmers to increase the size of their land, their productivity, and their external inputs and to minimize their labor force per hectare (Wilson 2007). Post-productivism and multifunctional agriculture allow farmers to choose their own focus and driving forces and take different paths for food production, so post-productivism and multifunctional farming will lead to differentiation and new rural spaces (Evans et al. 2002).

Multifunctional farmers, as agricultural entrepreneurs, are engaged in activities such as flowering, horticulture, medicinal plants, cultivating cash farming crops, poultry, aquaculture, livestock breeding, dairy processing, food industries, and other agricultural industries, while using modern methods of production, irrigation facilities, fertilizers, mechanized processing lines, new management systems, materials and techniques for controlling pests and diseases, and many other, to achieve greater returns and profits (Mohanty 2006). In this system, the increase productivity in the agricultural sector is mostly due to the effective use of inputs and sources, using modern technologies and management of agricultural systems. This requires the appropriate combination of 
knowledge and technology in agricultural chains from production to supply (APO 2003; Kanniainen and Timo 2005; Kreft et al. 2005).

Agricultural businesses are agricultural commercial units that link various agricultural chain rings and their management requires specialized knowledge and skill and the use of new technologies for value added, continuous improvement of productivity and improvement of the quality of products and services supplied to the market (APO 2003). Further, in these two periods, awareness about the importance and credibility of indigenous technical knowledge and the ability of the poor people to solve their problems increased (Rumbewas 2005).

The concepts of post-productivism and multifunctional agriculture are moving toward eco-friendly practices and use of knowledge inputs (knowledge-based) instead of physical inputs. Moving toward sustainable agriculture (organic agriculture and precision farming) is considered as part of the concepts of post-productivism and multifunctional agriculture (Wilson 2007). Knowledge based means that such systems, technologies, and activities require more delicate, precise, and complex forms of observation, analysis in field, and farm level action (Leeuwis 2004).

For many professionals, the environmental dimension is one of the important reasons for productivism/post-productivism transition. Certain researchers believed that post-productivism transition is basically an environmental transition, which is characterized as a period of severe environmental imbalances between food production and environmental protection (Wilson 2001). In fact, the solution to the environmental problems created by the agricultural sector was the responsibility of the sector which was conceptualized beyond productivism and denies the possibility of the development of environmental sensitive agricultural through the development of the principles of productivism (Evans et al. 2002). Postmodern theories take priority to environmental, ideological, and cultural issues-even if these goals are in conflict with maximum economic growth and a shift is being called from materialism to extra-material values (Eckersley 2005). Though, multifunctional agriculture, considering environmental issues and high emphasis on ecology and ecological care, also addresses economic issues, and it is believed that there is no conflict between economics and the environment (Wilson 2007).

\section{Researchers and agricultural extension in three transitional periods}

Political framework of productivism is based on subsidies and financial support for production. For this reason, the government is the main actor (Evans et al. 2002; Wilson 2007). Politically, post-productivism is manifested by the reduction of government subsidies and represents the movement from state-basis production models. Post-productivism is characterized by losing central agricultural position in the community (Wilson 2007). In this regard, rural development approaches are changed from a top-down development, blueprint, dependent on external technologies and government policies approach at the national level to a development approach in which planning is from the local level and bottom-up. In this approach, development was seen as a process, not a product. This approach transforms rural development into a participatory process that empowers villagers to determine their priorities in order to make certain change. Some of the key developmental features of this view are the emphasis on structural adjustment and 
market liberalization, which led to the withdrawal of governments from the large-scale agricultural management that was observable in the past (Rumbewas 2005). In post-productivism governmental support has decreased, competition in the farming sector has increased and the potential profits on many farms significantly decreased (Alsos et al. 2003; Vesala et al. 2007).

Agriculture in multifunctionality was considered valuable and important, but it was believed that agriculture is a multi-product activity, not a single product (Groenfeldt 2001). In multifunctional agriculture, the role and involvement of the government in the creation of markets for non-commodity products should not be overlooked. As the Organization for Development and Cooperation states, politics can help markets' regulation while compensating farmers by subsidies. The conceptualization of MFA helps to a better understanding of "potential sources of market failure for non-commodity outputs to provided theoretical arguments for correcting these cases with public intervention" (Renting et al. 2009).

In the concept of productivism, technological innovations were developed in research centers. In this regard, the researchers were not interested in going to the field and understanding the local strategies. In addition, research conditions with fertile soils, desirable facilities, and a large workforce could not represent the conditions of the rural community, which in most cases faces a shortage of labor and a lack of fertility (Warren et al. 2002). In such conditions, the production of knowledge and technology was essentially known as the duty of the scientists, and there was a strong belief that this process was guided and ruled over by researchers. In the context of post-productivism, researchers, in part, should be participants in farmers' research or stimulus for farmers (Leeuwis 2004). Researchers in multifunctional agriculture should act as innovation brokers. Innovation brokers paying to predict, diagnose and process of information and knowledge and combine and recombine it, test and validate, protect the results, commercialize, and evaluate the results. Innovation brokers act as facilitators (supporting the innovation process, but innovation is not created or transmitted by a specific provider). This contrasts with other interventions in which researchers play an important role in the initiation and development of innovation (Klerkx and Jansen 2010).

Within the modernization system, the main extension trajectory was based on a classic model in which extension agents were considered as known and well-informed people, while farmers were considered ignorant and uninformed. Based on the classic extension model, farmers were considered as passive people who should fill their brains with what extension agents know. Regarding this, the extension role base of the modernization paradigm was a mechanical role including the transfer of new ideas from the government or companies to farms and farmers agricultural training centers (Pillmann 2007; Ahmadvand and Karami 2007). In the concept of post-productivism, the role of extension has been attracting the active participation of villagers in creating, evaluating and diffusion of ideas in line with their biological, environmental, and psychological conditions (Chitnis 2005). In this regard, general public, farmers, extension agent, NGOs, and environmentalists have been considered as agricultural stakeholders (Ahmadvand and Karami 2007). In this sense, it is believed that the most appropriate way of improving and enhancing the scientific capital of farmers is not the transfer of knowledge, but improving the farmers' learning capacity to learn and experience themselves (i.e., to enhance exploratory and 
experimental learning) and extension agents should take the role of facilitators of individual and collective learning processes (Leeuwis 2004). In multifunctional agriculture, in addition of technology transfer, it is necessary that other supportive and capacity-making functions that help promoting entrepreneurship in the agricultural sector be considered. If the agricultural extension wants to go beyond the increase production and move toward inclusive subjects, it is necessary that the agricultural extension actors which are made up of interactive components understand the necessary changes and put purposeful efforts in their agenda for their implementation and institutionalization (APO 2003; Kanniainen and Timo 2005; Kreft et al. 2005).

In multicultural agriculture, "Institutional Economic Analysis (IEA)" and a "Sociological Network Analysis (SNA)" are defined as two applicable approach which should be considered in extension. Considering innovations to be highly recommended by the both approaches for agricultural actors, it is not as an exogenous feature but rather as a co-production among various actors including farmers, extension services, applied research institutes, etc. Agricultural innovations are not exogenous and linear and transmitted from research to farmers. Participatory approaches are highly recommended in the both frameworks in order to gain applicable knowledge (Labarthe 2009).

In productivism, the extension services are often supply driven and focus on a linear paradigm of innovation. But in MFA, a "one-size-fits- all" model of innovation and entrepreneurship support is inadequate. Considering this fact, coupled with the privatization of applied agricultural research institutes and agricultural extension services, has led to crucial changes in innovation and entrepreneurship support in agriculture and farmers are now supported by a pluralistic advisors' system (Klerkx and Jansen 2010).

However, agricultural extension was increasingly criticized for being as a part of a linear innovation system. Thus, agricultural firms require to create and maintain new relationships with external actor that needs to construct and optimize new social networks (Marsden et al. 2002). The development of innovation (both technical and institutional) by farmers requires knowledge and information input from the extension agents. Knowledge and information are exchanged and processed in interactive training streams and in the form of participatory (farmers, researchers, educators and extension agents, etc.) learning-teaching processes. Extension agents have to response to the special needs of farmers to receive information and perform the process, in order to generate knowledge and apply it with a participatory, contingent, and flexible approach. Strengthening the entrepreneurial knowledge and skills of farmers in order to integrate information, knowledge, and technology with contingency approach and change it to an optimal mix of production resources provides a way to achieve productivity in the agricultural sector (Sidhu and Sukhjeet 2006). It is obvious that the involvement of different stakeholders requires a process that is guided and controlled by a facilitator. These facilitators are supposed to have the knowledge and awareness to support and guide of learning, negotiation, and decision-making processes. Most importantly, it involves a negotiating process among stakeholders. This is because any significant change and escape from the current situation is probably accompanied by tension between those involved and affected by the problem (Leeuwis 2004). 


\section{View on farm and farmers in three transitional periods}

In productivism, rural people were known as passive and ignorant people, and communication and development professionals such as Rogers, Lazarsfeld, and Lasswell believed that improving people's knowledge and attitudes toward developing new ideas was possible by a linear one-way communication model and through mass media (Chitnis 2005). In fact, farmers should be dictated what to cultivate and how to keep their animals and crops against pests and diseases (Wilson 2007). In this period, farmers considered as farmers (engaged in farm-based economic activity) or a person who is unwilling to engage in diverse activities and is dependent on pressure factors. In this thinking, agricultural actors learn to act as craftsmen, producing food and fibers and development of an entrepreneurial identity, skills, and behavior that are not evident (Vesala et al. 2007). Postmodern logic emphasizes on cultural issues and the uniqueness of the individual and local experience; for this reason, an active role for farmers is usually considered (Rumbewas 2005). Multifunctional means that the farmer not only known as a producer of goods and services, but also recognized as the manager of environment and rural space, as well as being one of the main stakeholders in local development, seek to explore new business opportunities, build business networks, and measure and capture opportunities (Durand and Van Huylenbroek 2003). When diversification is considered as an expected agricultural practice, farmers are increasingly recognized as entrepreneurs while needing to develop new skills and capabilities to maintain their competitive ability (McElwee 2006; Vesala and Vesala 2010). Farmers have entrepreneurial orientation in a way that they are willing to innovate in order to improve market offerings, take risks, and try out new products, services, and markets, and be more active than other competitors in understanding market opportunities (Wiklund and Shepherd 2005; McElwee 2006).

In productivism, "farmers have been typically characterized as price takers, market followers and passive decision makers" (Wales Rural Observatory, 2011). Farmers in multifunctional agriculture become "price makers" (Pyysiäinen et al. 2006; De Wolf et al. 2007). In addition, some researchers have considered multifunctional farmers as portfolio entrepreneurs who simultaneously own and develop multiple businesses (Carter and Ram 2003). Considering recent activities, the focus is on that farmers are known as innovators, thus farmers' entrepreneurial skills have been taken into consideration. In productivism, all farm potentials and capacities are used and a mechanical perspective for production process is created (Wilson 2007). In this period, there is a roughly one-side concept of cultivation, and the farm is considered as a bundle of resources. In post-productivism agriculture, the farm is considered as an agro-ecological phenomenon because it is believed that the main task of designers of farm systems is ecological farming by replacing physical-chemical methods with biological methods (Leeuwis 2004). In multifunctional agriculture, the farm is seen as a firm. In fact, reduction of farmers' incomes has "led to increasing pressures to a reorientation from productivism to more entrepreneurial models of farming, with the result that farmers are increasingly required to become more market oriented, and to treat their 'farms as firms', in order to survive" (Jones et al. 2009; Meert et al. 2005; Phillipson et al. 2004). 
Therefore, as the results of the research show, entrepreneurship is the heart of multi-functional agriculture. Table 1 shows comparison of productivism, post-productivism, and multi-functional agriculture characteristics.

\section{Agriculture of Iran}

By 1960, Iranian agricultural system was traditional and subsistence (Taher Khani and Rahmani 2006). There was no particular ideology on this agricultural system. Agriculture had a central position in the villages, and the technologies were too simple and elementary. This agricultural system was based on the daily needs of farmers (Rezaei-Moghaddam et al. 2005). The agricultural cultivation pattern in traditional agricultural systems was based on the diversity of cultivation and the purpose of production was more to meet the household needs and self-consumption. Their planting and harvest were carried out on the basis of traditional activities, which were incorporated into their custom by parents and ancestors. Innovations were not continuously profitable, and their rate of adoption was slow. Biodiversity was a part of traditional practices which had been rooted in the need of farmers to be self-sufficient with greater diversity (Taher Khani and Rahmani 2006). This agricultural system could be called sustainable. This sustainability was not achieved consciously; indeed, it was because of the lack of knowledge of farmers in accessing the tools for harming the nature (Rezaei-Moghaddam et al. 2005). In this period, the system of land utilization called landlord-peasant. Land ownership belonged to the Khan, and the farmers named peasant was under the domination and guardianship of Khan by giving their workforce in the process of farming production and small amount of production was allocated to them, and agricultural production was carried out in the traditional system called Buneh in the agricultural and rural sectors (Amirani 2002). The main function of Buneh was the efficient exploitation of the land with the precise use of the available water in which, all of the members of each Buneh had the same social class including peasants and poor rural with low accessibility to the resources. Irrigator as Buneh's head, two assistants, and three sharecroppers were shaped the Buneh's members (Rezaei-Moghaddam et al. 2005).

In 1962, land reform took place in Iran. Land reform aimed at eliminating the power and influence of landlords and replacing state domination on rural areas led many farmers get landowner and created a small holding. This led each of them cultivate independently and structure of the Buneh subsequently collapsed. Therefore, the family farm utilization system expanded in Iran. In this type of utilization system, the main combination of cultivation is determined based on a mix of household livelihood and production needs for the market (Amirani 2002). The commercial utilization system and capitalism continued in two ways: first, through private sector investment in the area of personal and nationalized land belonging to the natural resources provided by the government to these units, and the second from 1968 is the current government decided to invest directly in agriculture through taking high quality and fertilizer agricultural land and using the modern and advanced technologies, through the established farm corporations and agro-industry units (Lahsai Zadeh 2008). 
Table 1 Comparison of productivism, post-productivism, and multi-functional agriculture characteristics

\begin{tabular}{|c|c|c|c|}
\hline & Productivism & Post-productivism & Multifunctionality \\
\hline \multirow[t]{4}{*}{ Philosophy } & $\begin{array}{l}\text { Positivism, absolute facts and } \\
\text { reality }\end{array}$ & Pluralism & $\begin{array}{l}\text { Pluralism, multiple realities and } \\
\text { relativism }\end{array}$ \\
\hline & $\begin{array}{l}\text { Modernization: linear progress } \\
\text { and economic } \\
\text { growth }\end{array}$ & $\begin{array}{l}\text { Post-modern: multiple } \\
\text { progress and sustainability }\end{array}$ & $\begin{array}{l}\text { Post-modern: multiple progress } \\
\text { and sustainability through social } \\
\text { innovation }\end{array}$ \\
\hline & $\begin{array}{l}\text { Agriculturist: central } \\
\text { hegemonic position of } \\
\text { agriculture in society }\end{array}$ & $\begin{array}{l}\text { Ecologist: loss of central } \\
\text { position of agriculture in } \\
\text { society }\end{array}$ & $\begin{array}{l}\text { Agriculturist and ecologist: an } \\
\text { agricultural systematic and } \\
\text { holistic point of view }\end{array}$ \\
\hline & $\begin{array}{l}\text { Traditional goods, general } \\
\text { business }\end{array}$ & Ecological services & $\begin{array}{l}\text { Innovative entrepreneurship } \\
\text { and } \\
\text { start-up of new ventures in } \\
\text { agricultural businesses }\end{array}$ \\
\hline \multirow{7}{*}{$\begin{array}{l}\text { Strategies } \\
\text { and } \\
\text { purpose }\end{array}$} & Emphasis on quantity & Emphasis on quality & $\begin{array}{l}\text { The emphasis on quality and } \\
\text { quantity }\end{array}$ \\
\hline & Science driven & Necessity driven & Opportunity driven \\
\hline & $\begin{array}{l}\text { Achieving self-sufficiency in } \\
\text { agricultural products }\end{array}$ & $\begin{array}{l}\text { Less emphasis on ensuring } \\
\text { self-sufficiency in agricultural } \\
\text { products }\end{array}$ & $\begin{array}{l}\text { Close relationship of food } \\
\text { security and self-sufficiency }\end{array}$ \\
\hline & $\begin{array}{l}\text { Increasing farms production, } \\
\text { capitalization of agriculture, } \\
\text { Intensification and } \\
\text { concentration of cultivation, } \\
\text { regional specialization of } \\
\text { production using external } \\
\text { inputs: resource base } \\
\text { agriculture }\end{array}$ & $\begin{array}{l}\text { Paying attention to local and } \\
\text { suburban areas, intensification } \\
\text { and dispersion of cultivation, } \\
\text { diversification, pluriactivity, } \\
\text { and diversification of } \\
\text { production patterns }\end{array}$ & $\begin{array}{l}\text { Paying attention to increasing } \\
\text { production, productivity, and } \\
\text { sustainability. Intensification as } \\
\text { well as on-farm diversification } \\
\text { activity. More coordination with } \\
\text { environmental protection } \\
\text { (knowledge base agriculture) }\end{array}$ \\
\hline & Economic rationality & Environmental rationality & $\begin{array}{l}\text { Environmental and economic } \\
\text { rationality }\end{array}$ \\
\hline & $\begin{array}{l}\text { An instrumental view of } \\
\text { nature: extreme expectancy } \\
\text { from the earth }\end{array}$ & $\begin{array}{l}\text { Nature is inherently } \\
\text { worthwhile: The amount of } \\
\text { land expected is equal to the } \\
\text { amount of land capability }\end{array}$ & $\begin{array}{l}\text { The environment is inherently } \\
\text { worthwhile: The amount of } \\
\text { resources expected is equal to } \\
\text { the amount of environmental } \\
\text { capability }\end{array}$ \\
\hline & $\begin{array}{l}\text { Technological relationship } \\
\text { with nature }\end{array}$ & $\begin{array}{l}\text { The wisely relationship of } \\
\text { technology with nature }\end{array}$ & $\begin{array}{l}\text { The wisely interaction of } \\
\text { technology with environment }\end{array}$ \\
\hline \multirow[t]{5}{*}{$\begin{array}{l}\text { Researchers } \\
\text { and } \\
\text { agricultural } \\
\text { extension }\end{array}$} & $\begin{array}{l}\text { Governmentalism: } \\
\text { government as central actor is } \\
\text { steering }\end{array}$ & $\begin{array}{l}\text { Negotiation and consensus } \\
\text { among various actors, the lack } \\
\text { of state-sector role }\end{array}$ & $\begin{array}{l}\text { Network of interdependent } \\
\text { actors: all actors are steering } \\
\text { (governmental, non- } \\
\text { governmental and private } \\
\text { institutions) }\end{array}$ \\
\hline & $\begin{array}{l}\text { Centralized: classical, } \\
\text { technocratic and rational } \\
\text { decision-making }\end{array}$ & $\begin{array}{l}\text { Decentralized: democratic } \\
\text { decision-making through } \\
\text { negotiation }\end{array}$ & $\begin{array}{l}\text { Decentralized: democratic } \\
\text { decision-making through } \\
\text { negotiation }\end{array}$ \\
\hline & $\begin{array}{l}\text { Strong financial and political } \\
\text { state support }\end{array}$ & $\begin{array}{l}\text { Reduced financial state } \\
\text { support }\end{array}$ & $\begin{array}{l}\text { Financial state support, } \\
\text { especially in the case of non- } \\
\text { commodity goods }\end{array}$ \\
\hline & Classical extension model & Participatory extension & $\begin{array}{l}\text { Pluralistic agricultural extension } \\
\text { systems } \\
\text { Combine two approaches: IEA } \\
\text { and SNA }\end{array}$ \\
\hline & $\begin{array}{l}\text { The function of extension } \\
\text { agent is diffusion of new } \\
\text { patterns of production, } \\
\text { technologies and activities }\end{array}$ & $\begin{array}{l}\text { Extension agent as facilitators } \\
\text { of individual and collective } \\
\text { learning processes } \\
\text { Services to marginal groups }\end{array}$ & $\begin{array}{l}\text { Functional diversity: } \\
\text { participatory development of } \\
\text { technology, capacity building, } \\
\text { facilitating, and mentoring, } \\
\text { providing consultancy services } \\
\text { Diffusion of entrepreneurship } \\
\text { and development of new } \\
\text { businesses }\end{array}$ \\
\hline
\end{tabular}


Table 1 Comparison of productivism, post-productivism, and multi-functional agriculture characteristics (Continued)

\begin{tabular}{|c|c|c|c|}
\hline & Productivism & Post-productivism & Multifunctionality \\
\hline \multirow{6}{*}{$\begin{array}{l}\text { View on } \\
\text { farm and } \\
\text { farmers }\end{array}$} & $\begin{array}{l}\text { Transfer of technology } \\
\text { through rich contact farmers }\end{array}$ & $\begin{array}{l}\text { Transfer of technology } \\
\text { through all farmers and all } \\
\text { rural people }\end{array}$ & $\begin{array}{l}\text { Transfer of technology through } \\
\text { all farmers and all rural people } \\
\text { and other stakeholders }\end{array}$ \\
\hline & $\begin{array}{l}\text { Researcher as an owner of } \\
\text { research process }\end{array}$ & $\begin{array}{l}\text { Researcher as a participants in } \\
\text { farmers research or stimulator } \\
\text { of farmers }\end{array}$ & $\begin{array}{l}\text { Researcher as a proficient in } \\
\text { innovation process, } \\
\text { Researcher as "broker" or } \\
\text { "boundary spanner" }\end{array}$ \\
\hline & $\begin{array}{l}\text { The mechanical view of farm: } \\
\text { the farm is agro-economic } \\
\text { phenomenon }\end{array}$ & $\begin{array}{l}\text { The farm is agro-ecology } \\
\text { phenomenon }\end{array}$ & $\begin{array}{l}\text { The farm is agro-ecology- } \\
\text { economic phenomenon which } \\
\text { is formed in a social context. }\end{array}$ \\
\hline & $\begin{array}{l}\text { One-sided concept of } \\
\text { cultivation }\end{array}$ & $\begin{array}{l}\text { Multi-dimensional concept of } \\
\text { cultivation }\end{array}$ & $\begin{array}{l}\text { Farms as potential } \\
\text { multifunctional rural companies }\end{array}$ \\
\hline & $\begin{array}{l}\text { Passive learner: one-way } \\
\text { relationship } \\
\text { Education and internship } \\
\text { patterns }\end{array}$ & $\begin{array}{l}\text { Active learner: collective } \\
\text { methods, participatory } \\
\text { approaches } \\
\text { Pluriactive farmers }\end{array}$ & $\begin{array}{l}\text { Active learner: collective } \\
\text { methods, participatory } \\
\text { approaches and multi-actors } \\
\text { learning }\end{array}$ \\
\hline & Farmers as farmers & $\begin{array}{l}\text { Farmers as environmental and } \\
\text { countryside managers }\end{array}$ & $\begin{array}{l}\text { Farmers as entrepreneurs: acting } \\
\text { as environmental and } \\
\text { countryside managers, and as } \\
\text { rural entrepreneurs }\end{array}$ \\
\hline
\end{tabular}

Green revolution as a subset of high pay-off input model was the dominant agricultural policy at that point of the time (Forouzani and Karami 2010). This has been accompanied by the replacement of subsistence farming patterns with crop production for export and the simultaneous elimination of a sustainable traditional farming system. At this time, the main concern of agriculture was maximum food production to ensure national or regional self-sufficiency. Policy structures were top-down and high inputs and heavy machinery was used as an agricultural technique. Thus, Iran experienced a double setback. One by industrialization of agriculture and using modern agriculture's package of high-yield varieties, fertilizers, pesticides and heavy irrigation and the other with occurrence White Revolution's land reforms (Karimi 2009).

The modernization was not as a result of society natural transformation in Iran, since the emphasis of modernity was on universality and integrity; the technologies that were created in the rainy areas of Europe and the USA were prescribed for a climate and a relatively unfavorable environment of Iran. Oil revenue countries intend to use capitalist technologies. With use of these technologies, not only the income of other economic sector did not increase, but also the income of some sectors such as agriculture had stagnation. For this reason, modernization of agriculture has left many adverse effects on the Iranian agricultural sector (Rezaei-Moghaddam et al. 2005).

\section{Research method}

In order to evaluate the six development plans of Iran regarding different agricultural transition periods, quantitative content analysis method was used for the objective, regular, and quantitative description of communication messages (Rezayat 2012). In a quantitative content analysis approach, the goal is to measure the number of the subject concepts. The stages of content analysis in this study, according to Gall et al. (2007), include six steps: "Identification of research documents," "Formulation of questions, 
hypotheses and research purpose," "Selection a sample of documents," "Set classification method," "Account frequency of each category," and "Interpretation of results." It should be noted that researchers have used "Deductive category application." Because development plans have been analyzed with respect of extracted categories and sub-categories about agricultural transition periods. Deductive content analysis is often used in cases where the researcher wishes to retest existing data in a new context. This may also involve testing categories, concepts, models, or hypotheses. If a deductive content analysis is chosen, the next step is to develop a categorization matrix and to code the data according to the categories (Elo and Kyngäs 2007). Researchers' approach to content analysis was quantitative. In quantitative content analysis methods, the text or documents are counted according to a quantitative number of categories. In this research, the text of development plans has been counted and compared with each other according to the frequency of each categories and sub-categories of agricultural transition periods. Descriptive criteria are categories and sub-categories related to agricultural transition periods. The research analysis unit of this study includes each development plans and the recording unit contains phrases, propositions, sentences, and words of the development plans that include the contents and concepts related to the categories and subcategories of the agricultural transition periods. In order to increase the processing power of data in content analysis and to determine the priority and process of attention to the triple periods of agriculture in the six planning development periods of Iran, a Hierarchical Additive Weighting Method of decision-making models was used. These models are the basis for prioritizing a number of options based on some indices. In the HAW method, effective factors and sub factors in decision-making are expressed in a hierarchical order (Pourtaheri 2010).

In this paper, a three-level model including the goal of decision-making at the first level, the indicators affecting on decision-making purpose in second level, and policy documents of six development plans regarding agricultural sector at third level was used. In these models, determining the indices weights is very important for assessing the importance of each index regarding to other indices. The selection of decision-making model and weighting is based on available information. According to obtained information from the content analysis, Shannon entropy weighting method was used. This method calculates the weights of each index based on the distribution of the values of the indices. In this paper, to prioritize the plans based on the steps of the HAW decision-making model, the existing status matrix (transition matrix) consisting of six rows (options) and three columns (indicators) was developed and the sum of the frequencies obtained from content analysis of agricultural policies put in the related cell for each indicator. Then, the options weight for each index was calculated by standardizing the digits of each column with the number 1 function and the obtained standard matrix $\left(W_{3}\right)$ was plotted. To calculate the weights of the indices $\left(W_{2}\right)$ using the Shannon entropy method, after plotting the existing status matrix and normalizing its values with function No. 1, function number 2 was used to calculate the entropy of the $j^{\text {th }}$ indices $\left(E_{\mathrm{j}}\right)$, and then the uncertainly $\left(d_{\mathrm{j}}\right)$ was calculated with function number 3 and finally the weight of the indices in entropy method was calculated with function 4 . 
In these functions, $m$ is the number of options and $n$ is the number of indices (Pourtaheri 2010; Azar 2001).

Function 1:

$$
P_{i j}=\frac{a_{i j}}{\sum_{i=1}^{6} a_{i j}}
$$

Function 2:

$$
E_{j}=-K \sum_{i=1}^{m}\left[P_{i j} \ln P_{i j}\right] ; \forall_{j} K=\frac{1}{\ln (m)}
$$

Function 3:

$$
d_{j}=1-E_{j} ; \forall_{j}
$$

Function 4:

$$
W_{j}=\frac{d_{j}}{\sum_{j=1}^{n} d_{j}}
$$

\section{Results and discussion}

\section{Iran development plans in three agricultural transition periods}

Table 2 shows the emphasis on each agricultural periods. The highest emphasis on productivism was in the first program with $98.51 \%$, and the second program with $76.25 \%$ was in second rank. In next programs, the emphasis has decreased, but the percentage of emphasis has been higher than post-productivism and multi-functionality. In sixth program, multifunctional agriculture (38.98\%) has been emphasized more than other programs, and the most emphasis on post-productivism agriculture was in the fourth plan.

According to Fig. 2, the focus of six programs has been on productivism (67.37) and multifunctional agriculture (23.95) and post-productivity (8.68) have been ranked second and third respectively.

In order to determine the priority and the process of paying attention to agricultural transition periods in agricultural policies of development plans based on the HAW method, decision-making matrix of the existing situation consists of three indicators in the row (productivism, post-productivism, and multifunctional agriculture) and six options in the columns (programs) were formed (Table 3) and then the standard matrix $\left(W_{3}\right)$ was calculated (Table 4).

The calculated weights of each index by the entropy method shows in Table 5 . According to these results, productivism has the lowest and post-productivism has the highest weight, which means that the emphasis of development plans is moving toward the further involvement of post-productivism in decision-making.

\section{Conclusion}

In the next few years, an innovative or knowledge-based economy, which consider the production and use of knowledge and innovation as a source of wealth and competitive advantage will replace the traditional economy. This movement affects all sectors, and agriculture is no exception to this rule. Considering changes occurred in the economy over the past decades, agricultural productivism will no longer be responsive, and its 


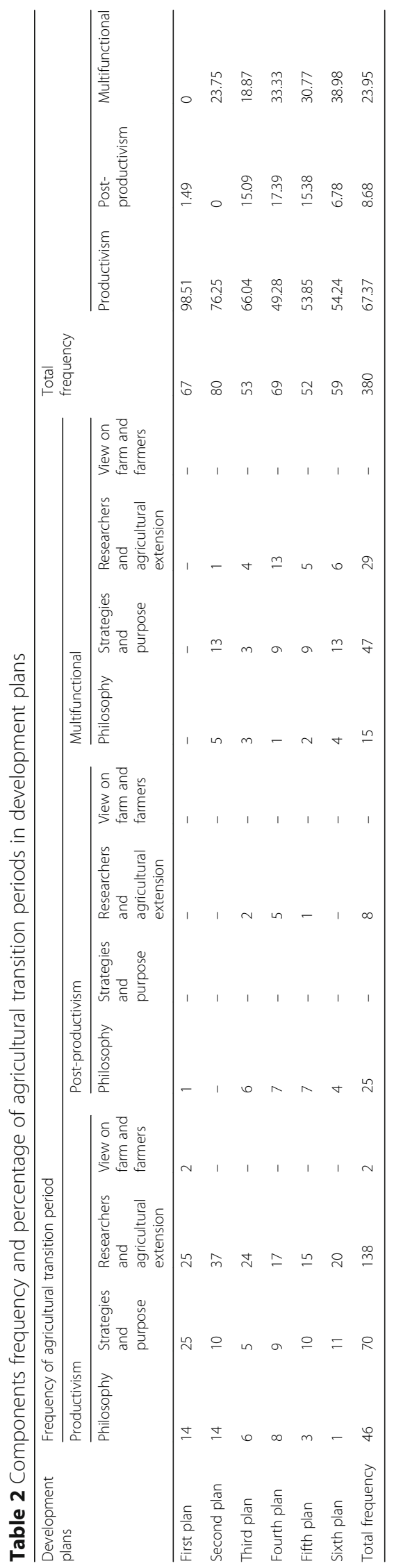




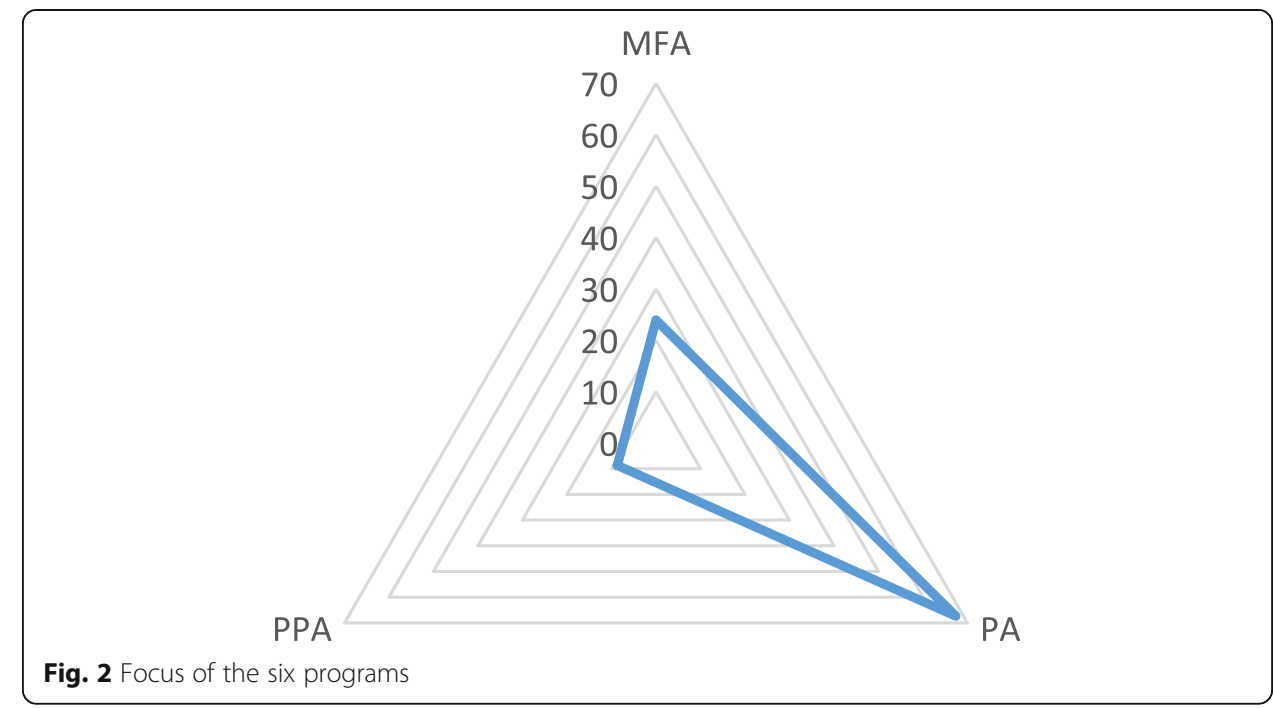

change is inevitable. Also, the concept of post-productivism cannot reflect the changes in agricultural and rural areas well. First, this term represents a linear and bipolar process of changes which the two productivism and post-productivism terms are on the two ends of a spectrum, while the reality of the agricultural and rural community is not like this, and secondly, the "post" term here represents the transition from one stage to another, but is the reality like this?

The game rules are changing for the agricultural sector, and this sector must adapt to these changes in order to cope with the challenges. Multifunctional agriculture seems to be a better alternative in which entrepreneurship is at the center of it. Politicians, experts, and scientists all agree that farmers, along with farm management, cultivation, and planting, need entrepreneurship to be stable in the future (McElwee 2008; Lans et al. 2016). Farmers need to search for diverse sources of income like non-farm activities due to the environmental, social, and economic crisis. These kind of farmers have strongly been recognized as entrepreneurs (Alsos et al. 2011; Vesala and Vesala 2010).

Iran is in the era of the factor-driven economy and is in the process of transition from this stage. Iran is currently facing triple challenges to make agricultural sector more sustainable, more profitable and more productive. Because of the prevailing economic theory, productivism agricultural system is being implemented in Iran, where overuse of resources and the use of agricultural chemical inputs have made Iran face a crisis. It seems that Iran can also benefit from multifunctional agriculture toward sustainable agriculture and the production of healthy food. Therefore, it should be seen

Table 3 Existing status matrix regarding agricultural transition period in development plans

\begin{tabular}{llll}
\hline & Productivism & Post-productivism & Multifunctional \\
\hline First plan & 0.26 & 0.03 & - \\
Second plan & 0.24 & - & 0.21 \\
Third plan & 0.14 & 0.24 & 0.11 \\
Fourth plan & 0.13 & 0.36 & 0.25 \\
Fifth plan & 0.11 & 0.24 & 0.18 \\
Sixth plan & 0.13 & 0.12 & 0.25 \\
\hline
\end{tabular}


Table 4 Standardize matrix

\begin{tabular}{llll}
\hline & Productivism & Post-productivism & Multifunctional \\
\hline First plan & 66 & 1 & - \\
Second plan & 61 & - & 19 \\
Third plan & 35 & 8 & 10 \\
Fourth plan & 34 & 12 & 23 \\
Fifth plan & 28 & 8 & 16 \\
Sixth plan & 32 & 4 & 23 \\
Sum & 256 & 33 & 91 \\
\hline
\end{tabular}

$K=0 / 55811$

whether the existing policies of Iran are in line with this new thinking in the agricultural sector or not? Studies have shown that the most emphasis of the Iran's policies is on agricultural productivism, as well as the emphasis of developmental programs are mostly toward more involvement of post-productivism in decision-making. It seems that, given the criticisms of post-productivism, the implementation of this concept will not be able to solve the problems facing Iran's agricultural sector, and a more comprehensive conception on Iranian rural and agricultural thought and practice needs to be established. In fact, one of the main strategies to exit the defective cycle of unsustainable increase of production and destruction of basic resources and in order to solve the basic problems of the agricultural sector is multifunctional agriculture. Encouraging agricultural development by relying on multifunctional agriculture is not a simple task and requires the redefining of some identities, strategies, behaviors, relationships, and networks (Van der Ploeg et al. 2000). Thus, it requires changes in the policies and the organizational environment. According to Fig. 3, moving toward multifunctional agriculture which is the same as entrepreneurial agriculture, firstly, the economic theory should be changed and taken toward an innovative economy. As a consequence, the agricultural system should also be changed and multicultural agriculture should be considered. Researchers believe that entrepreneurship in the agricultural sector will increase if there is an enabling environment that promotes entrepreneurial activities (Kavari 2016). From a generalist perspective, the development of entrepreneurship in the agricultural sector must be considered in the macro-national development system. Policies and economic, social, cultural, and political system implications reflected in macro-national economic development programs, such as the 5-year development plan, the 20-year vision and macro-system policies, are like a strategic umbrella. This umbrella is a conductor, provider, and directional of various economic subdivisions. On the other hand, the development of all sectors, including the agricultural sector, is due to the establishment and continuation of the effective actor systems. The overlap between sub-systems and sectors in relation to the agricultural sector has led to the formation of an institutional actor area called the interactive systems of education,

Table 5 Entropy, unconfidency, and index weights of agricultural transition period

\begin{tabular}{llll}
\hline & Productivism & Post-productivism & Multifunctional \\
\hline Indices entropy & 0.97 & 0.79 & 0.88 \\
Unconfidency & 0.03 & 0.21 & 0.12 \\
Indices weights & 0.083 & 0.583 & 0.333 \\
\hline
\end{tabular}




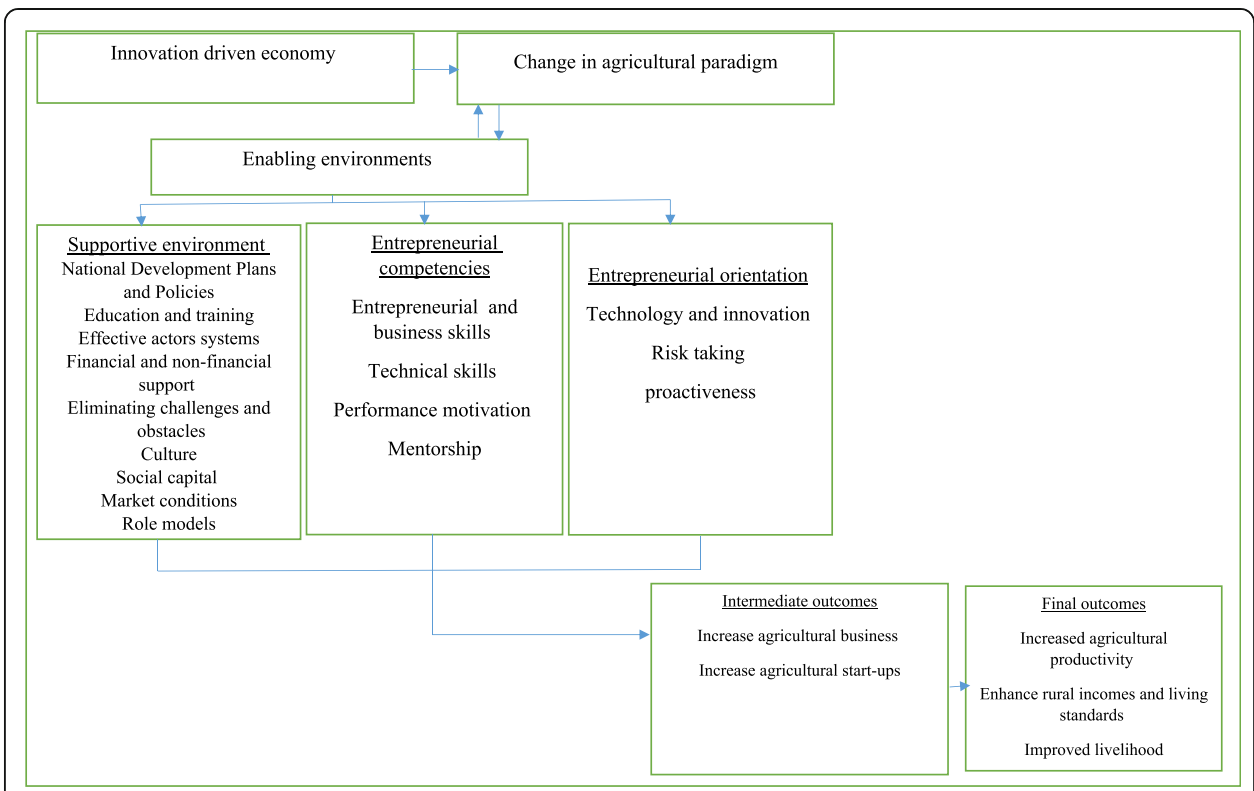

Fig. 3 A conceptual model on agricultural-entrepreneurial development (adopted by (Kavari 2016))

research and extension, etc. within the institutional framework of the knowledge and information system and agricultural technology. To achieve sustainable development in line with the macro-system policies the agricultural sector faces a number of challenges and crises, some of which have become chronic as a result of the continuation and institutionalization of the roots, which must be obviated. Developing of non-traditional attitude, entrepreneurial intentions, competencies, identities, and entrepreneurial experiences among young future farmers requires various studies on the role of agricultural education. Entrepreneurial thinking in agriculture should be considered in the curricula of the agricultural universities worldwide (Hulsink et al. 2014).

\section{Abbreviations}

HAW: Hierarchical Additive Weighting Method; MFA: Multifunctional agriculture; OECD: Organization for Economic Cooperation and Development; PA: Productivism agriculture; PPA: Post-productivism agriculture

\section{Acknowledgements}

We acknowledge the support from Shiraz University School of Agriculture, Department of Agricultural Extension and Education and Trento university, Department of Economics and Management.

Funding

The needed funding for the study provided by the Shiraz University.

\section{Availability of data and materials}

The datasets generated and/or analyzed during the current study are not publicly available due [Because all of the data was gathered by the research team] but are available from the corresponding author on reasonable request.

Duplicate publication policy

The authors declare and confirm that the content of manuscript has not been published, or submitted for publication elsewhere. 


\section{Competing interests}

In the previous research, productivism and post-productivism periods have been investigated but we developed categories and subcategories and compared multifunctional farming with the two previous periods and investigated that how multifunctional agriculture can help develop entrepreneurship in the agricultural sector. Also, the content of six developmental plans of Iran was considered according to the categories and sub categories of agricultural transition periods; the emphasis rate of various agricultural periods during the six development plans has been identified and compared with each other which has not been considered in previous studies.

\section{Publisher's Note}

Springer Nature remains neutral with regard to jurisdictional claims in published maps and institutional affiliations.

Received: 27 November 2018 Accepted: 15 January 2019

Published online: 09 February 2019

\section{References}

Acs, Z. J., Desai, S., \& Hessels, J. (2008). Entrepreneurship, economic development and institutions. Small Business Economics, 31, 219-234.

Ahmadvand, M., \& Karami, E. (2007). Sustainable agriculture: Towards a conflict management based agricultural extension. Journal of Applied Science, 7(24), 2880-2890.

Alsos, G. A., Carter, S., Ljunggren, E., \& Welter, F. (2011). The handbook of research on entrepreneurship in agriculture and rural development. Cheltenham/Northampton: Edward Elgar.

Alsos, G. A., Ljunggren, E., \& Pettersen, L. T. (2003). Farm-based entrepreneurs: what triggers the start-up of new business activities? Journal of Small Business and Enterprise Development, 10(4), 435-443.

Amirani, M. H. (2002). Review of land use system in Iran. Jehad, 19(230-231), 117-128.

APO. (2003). Development of Agribusiness Enterprises (editted by Robert Oliver), Report of the APO Seminar on Development of Agribusiness Enterprises (Indonesia, 20-24 November 2000). Tokyo: Asian Productivity Organization.

Azar, A. (2001). Extending and developing the Shannon entropy for data process in content analysis. Journal of Humanities, $11(37-38), 1-18$

Bosma, N., Acs, Z. J., Autio, E., Coduras, A., \& Levie, J. (2012). Global Entrepreneurship Monitor 2008 Executive Report, London, U.K. Babson College: London Business School and Babson Park.

Brouma, A. D. (2003). Bridging the GAP: modernity versus post-modernity. Which water management paradigm? Paper prepared for the Kokkalis Graduate Workshop Harvard University.

Carter, S., \& Ram, M. (2003). Reassessing portfolio entrepreneurship. Small Business Economic, 21, 371-380.

Chitnis, S. K. (2005). Communication for empowerment and participatory development: a social model of health in Jamkhed, India. The College of Communication of Ohio University: A dissertation presented for degree of doctor.

Darvishi, A. K. (2003). Capacity and ability of sustainable development in Iran. Iranian Journal of Agricultural Economic and Development, 5(2), 30-53.

De Wolf, P., Schoorlemmer, H., \& Rudmann, C. (2007). Important trends and required skills: an international synthesis. In P. D. Wolf \& H. Schoorlemmer (Eds.), Exploring the significance of entrepreneurship in agriculture (pp. 104-124). Frick: Research Institute of Organic Agriculture FiBL.

De Vries, B. (2000). Multifunctional agriculture in the international context: a review. The land stewardship project. Minneapolis, USA.

Durand, G., \& Van Huylenbroek, G. (2003). Multifunctionality and rural development: a general framework. In G. Van Huylenbroek \& G. Durand (Eds.), Multifunctional agriculture: a new paradigm for European agriculture and rural development (pp. 1-18). Aldershot: Ashgate.

Eckersley, R. (2005). The challenge of post-materialism. Australian Financial Review, 24, 5-10.

Elo, S., \& Kyngäs, H. (2007). The qualitative content analysis process. JAN: Research Methodology.

Essex, S. (2005). Rural change and sustainability: agriculture, the environment and communities. Wallingford: CABI Publishing.

Evans, N., Morris, C., \& Winter, M. (2002). Conceptualizing agriculture: a critique of post-productivism as the new orthodoxy. Progress in Human Geography, 26(3), 313-332.

Fernandez-Cornejo, J., Nehring, R., Hendricks, C., Southern, M., and Gregory, A. (2007). Off-farm income, technology adoption and farm economic performance. US Department of Agriculture. Economic Research Report. No. 7234.

Forouzani, M., \& Karami, E. (2010). Agricultural water poverty index and sustainability. Journal of Agronomy for Sustainable Development, 31(2), 415-431.

Gall, M. D., Gall, J. P., \& Borg, W. R. (2007). Educational research: an introduction (8th ed.). Needham Heights MA: Allyn \& Bacon. Galloway, L., \& Mochrie, R. (2005). The use of ICT in rural firms: a policy-orientated literature review. information, 7(3)), 33-46.

Goodman, D. (2004). Rural Europe redux? Reflections on alternative agro-food networks and paradigm change. Sociologia Ruralis, 44, 3-16.

Groenfeldt, D. (2001). How the multifunctionality concept can restore meaning of agriculture. In B. Havenkort \& C. Reijntjes (Eds.), Moving world views: reshaping sciences, policies and practices for endogenous sustainable development (pp. 230-236). Lesden: Compass series on worldviews and sciences.

Hulsink, W., Dons, H., Lans, T., \& Blok, V. (2014). Boosting entrepreneurship education within the knowledge network of the Dutch agri-food sciences: the new 'Wageningen'- approach. In Handbook on the Entrepreneurial University (pp. 248-278). Cheltenham: Edward Elgar Publishing.

Ilbery, B. W. (1991). Farm diversification as an adjustment strategy on the urban fringe of the west midlands. Journal of Rural Studies, 7(3), 207-218.

Illinois, U. (2015). Greening the common agricultural policy: Past experiences and future challenges toward multifunctional agriculture. University of Illinois, Urbana-Champaign: Master thesis.

Jack, L. (2007). Accounting, post-productivism and corporate power in UK food and agriculture. Critical Perspectives on Accounting, 18, 905-931. 
Jenkins, N. T. (2000). Putting postmodernity into practice: endogenous development and the role of traditional cultures in the rural development of marginal regions. Ecological Economics, 34, 301-314.

Jones, D., Moreddu, C., \& Kumagai, T. (2009). The role of agriculture and farm household diversification in the rural economy: Evidence and initial policy implications. Paris: OECD.

Kalantari, K., Shabanali Fami, H., Asadi, A., Qasemi, I., \& Chubchian, S. (2008). Major challenges of Iranian rural communities for achieving sustainable development. American Journal of Agricultural and Biological Sciences, 3(4), 724-728.

Kanniainen, V., \& Timo, V. (2005). Entrepreneurship and labor market institutions. Economic Modeling, 22(5), 828-847.

Karbasioun, M., Mulder, M., \& Biemans, H. (2008). Changes and problems of agricultural development in Iran. World Journal of Agricultural Sciences, 4(6), 759-769.

Karimi, A. A. (2009). Water situation in Iran: challenges and achievements. In: European water and sanitation services vs. sustainable development, potable water services in Morocco-China-Austria-Iran, Proc. November, 2009, Athens.

Kavari, U. J. (2016). Modelling an agricultural-entrepreneurial development resolution. University of Pretoria: Ph.D. thesis.

Klerkx, L., \& Jansen, J. (2010). Building knowledge systems for sustainable agriculture: supporting private advisors to adequately address sustainable farm management in regular service contacts. International Journal of Agricultural Sustainability, 8(3), 148-163.

Knickel, K., \& Renting, H. (2000). Methodological and conceptual issues in the study of multifunctionality and rural development. Sociologia Ruralis, 40(4), 512-528.

Kreft, S. F., Russell, S., \& Sobel, T. (2005). Public policy, entrepreneurship, and economic growth. Cato Journal, 25(3), 595-616.

Labarthe, P. (2009). Extension services and multifunctional agriculture. Lessons Learnt from the French and Dutch Contexts and Approaches. Journal of Environmental Management, 90, 193-202.

Lahsai Zadeh, A. A. (2008). Rural development sociology. 2000. Shiraz: Zar Publishing.

Lans, T., Verhees, F., \& Verstegen, J. (2016). Social competence in small firms_-fostering workplace learning and performance. Human Resource Development Quarterly, 27(3), 321-348.

Leeuwis, C. (2004). Communication for rural innovation: rethinking agricultural extension (3rd ed.). Ede: Technical Centre for Agricultural and Rural Cooperation.

Losch, B. (2004). Debating the multifunctionality of agriculture: From trade negotiations to development policies by the south. Journal of Agrarian Change, 4(3), 336-360.

Marsden, T., Banks, J., \& Bristow, G. (2002). The social management of rural nature: Understanding agrarian-base rural development. Environmental and Planning A: Economy and Space, 34, 809-825.

Marsden, T., \& Sonnino, R. (2008). Rural development and regional state: denying multifunctional agriculture in UK. Journal of Rural study, 24, 422-431.

Mather, A., Hill, G., \& Nijnik, M. (2006). Post-productivism and rural land use: Cul desac or challenge for theorization? Journal of Rural Study, 22, 441-455.

McElwee, G. (2006). Farmers as entrepreneurs: developing competitive skills. Journal of Developmental Entrepreneurship, $11(3), 187-206$.

McElwee, G. (2008). Taxonomy of entrepreneurial farmers. International Journal of Entrepreneurship and Small Business, 6(3), 465-478.

Meert, H., Van Huylenbroeck, G., Vernimmen, T., Bourgeois, M., \& Van Hecke, E. (2005). Farm household survival strategies and diversification on marginal farms. Journal of Rural Studies, 21(1), 81-97.

Mohanty, S. K. (2006). Fundamentals of entrepreneurship. New Delhi: Prentice Hall of India.

Peng, X. (2007). A comparative study of knowledge-based economy development between China and the USA. Data Science Journal, 6.

Phelan, C. (2014). Understanding the farmer: an analysis of the entrepreneurial competencies required for diversification to farm tourism. University of Central Lancashire: Ph.D thesis.

Phillipson, J., Gorton, M., Raley, M., \& Moxey, A. (2004). Treating farms as firms? The evolution of farm business support from Productionist to entrepreneurial models. Environment and Planning C: Government and Policy, 22(1), 31-54.

Pillmann, W. (2007). Environmental communication systems analysis of environmentally related information flows as a basis for the popularization of the framework for sustainable development. Vienna: International Society for Environmental Protection (ISEP).

Pourtaheri, M. (2010). Application of multi-attitude decision making methods in geography. Tehran: SAMT Publication.

Pyysiäinen, J., Anderson, A., McElwee, G., \& Vesala, K. (2006). Developing the entrepreneurial skills of farmers: some myths explored. International Journal of Entrepreneurial Behaviour \& Research, 12(1), 21-39.

Renting, H., Rossing, W. A. H., Groot, J. C. J., Ploeg, J. D., Laurent, C., Perraud, D., Stobbelaar, D. J., \& Ittersum, M. K. (2009). Exploring multifunctional agriculture: a review of conceptual approaches and prospects for an integrative transitional framework. Journal of Environmental Management, 90, 5112-5123.

Rezaei-Moghaddam, K., Karami, E., \& Gibson, J. (2005). Conceptualizing sustainable agriculture: Iran as an illustrative case. Journal of Sustainable Agriculture, 27(3), 25-56.

Rezayat, G. H. (2012). Educational booklet of content analysis workshop with emphasis on content analysis of scientific interview. Iranian Higher Education Association.

Rumbewas, S. (2005). Poverty in three villages in Papuna. Massey University: A thesis presented in fulfilment of the Requirement for the degree of Doctor of Philosophy in Development Studies.

Sidhu, K., \& Sukhjeet, K. (2006). Development of Entrepreneurship among Rural Women. Journal of Social Science, 13(2), 147-149

Taher Khani, T., \& Rahmani, D. (2006). An analysis of cultivation pattern specialization and its role in rural development: the case of strawberry cultivation in Javaroud Marivan region. Planning and space aligment, 1(10), 81-102.

Van der Ploeg, J. D., Renting, H., Brunori, G., Knickel, K., Mannion, J., Marsden, T., de Roest, K., Sevilla-Guzmán, E., \& Ventura, F. (2000). Rural development: from practices and policies towards theory. Sociologia Ruralis, 40(4), 392-408.

Vermillion, L. D. (2000). Old and new paradigm for water and development. Workshop in water resources and irrigation sector reform: Principle and framework of program implementation. October 3-4, 2000. Jakarta.

Vesala, H. T., \& Vesala, K. M. (2010). Entrepreneurs and producers: Identities of Finnish farmers in 2001 and 2006. Journal of Rural Studies, 26(1), 21-30.

Vesala, K. M., Peura, J., \& McElwee, G. (2007). The split entrepreneurial identity of the farmer. Journal of Small Business and Enterprise Development, 14(1), 48-63. 
Wales Rural Observatory. (2011). Report on Farmers' Decision Making. http://www.walesruralobservatory.org.uk/sites/default/ files/Farmers\%27\%20Decision\%20Makig\%20Final\%20Report.pdf. Accessed 1 Sept 2016.

Warren, P., Dara, J., \& Mckinnon, J. (2002). Steps towards sustainable rural development through appropriate technology and participation in Northwestern Cambodia.

Wiklund, J., \& Shepherd, D. (2005). Entrepreneurial orientation and smakk business performance: a configuration approach. Journal of Business Venturing, 20(1), 71-91.

Wilson, G. A. (2001). From Productivism to Post-Productivism... And Back Again? Exploring the (Un) Changed Natural and Mental Landscapes of European Agriculture. Transactions of the Institute of British Geographers, 26(1), 77-102.

Wilson, G. A. (2007). Multifunctional agriculture: a transition theory perspective. Wallingford: CAB International.

Wilson, G. A. (2008). From 'weak' to 'strong' multifunctionality: conceptualising farm-level multifunctional transitional pathways. Journal of Rural Study, 24(3), 367-383.

Wilson, G. A. (2009). The spatiality of multifunctional agriculture: a human geography perspective. Geoforum, 40, 269-280. Wilson, G. A., \& Wilson, O. (2001). German agriculture in transition: society, politics, and environment in a changing Europe. Basingstoke: Palgrave Macmillan

Woods, M. (2010). Rural. London: Routledge.

Yazdani, H., \& Saeedi, G. H. (2014). Position of the knowledge-based economy in the process of economic development. Tehran: Vice President of Strategic Planning and Control.

Submit your manuscript to a SpringerOpen ${ }^{0}$ journal and benefit from:

- Convenient online submission

- Rigorous peer review

- Open access: articles freely available online

- High visibility within the field

- Retaining the copyright to your article

Submit your next manuscript at $>$ springeropen.com 